\title{
EL SOLAR AND LA VIVIENDA VERNÁCULA AS EXAMPLES OF TRADITIONAL HOME CONSTRUCTION IN MEXICO'S YUCATÁN
}

DOI: http://dx.doi.org/10.18509/GBP.2018.26

UDC: $930.85(721 / 727)$

\author{
Anna Winiarczyk-Raźniak \\ Piotr Raźniak \\ Institute of Geography, Pedagogical University of Cracow, Poland
}

\begin{abstract}
The descendants of the Maya living in modern-day Mexico distinguish themselves via language and advanced culture with respect to all other ethnic groups in the country. Features characteristic of the Maya include their dress, customs, and traditional living quarters. Their unique style of home construction is the result of their social and economic status and benefits generated by this form of traditional architecture. However, a number of factors are causing a decline in this traditional form of home construction. Two related factors are modernization and development in rural areas in Mexico. Another key factor is the perception that traditional ways of life and forms of housing are forms of backwardness. This is a view held by many in Mexican society. Many individuals have forgotten that traditional forms of architecture yield certain benefits unavailable elsewhere including the use of natural materials and technologies, ability to create ethnic and regional identity via housing traditions, and traditional ways of life that help the poor survive. All of these reasons may serve as an important basis for action that is designed to help foster sustainable development on a social level and a regional level. One additional reason to protect traditional ways of life is related to the promotion of tourism in a given geographic region.

The present study examines traditional home construction, as practiced by the modernday Maya inhabitants of three Mexican states in the Yucatan Peninsula: Campeche, Quintana Roo, Yucatán. The study relies on statistical data obtained from the Mexican census: Encuesta Intercensal 2015 en Mexico. It also uses data obtained from other sources including fieldwork in the region. The study yields key characteristics of traditional housing and their distribution across geographic space in the study area.
\end{abstract}

\section{INTRODUCTION}

The present-day Maya population consists of descendants of a highly developed human civilization. It occupies areas in the present-day countries of Mexico, Guatemala, Belize, and Honduras. The key characteristic of this roughly six-million population is its use of the Maya group of several dozen languages [10]. However, it is also quite diverse in terms of culture, as manifested by slightly different dress, religious practices, and the dates and types of holydays celebrated by each group of Maya.

The present study examines traditional housing produced by the Maya currently inhabiting the Yucatan Peninsula in southeastern Mexico. The Maya homeland consists largely of lowlands situated atop permeable limestone rocks with multiple signs of karst forming limestone caves known as cenotes. The region is covered with tropical forests growing across semi-desert-type plains as well as chapparal-type plant communities that consist of sclerophyllous bushes and trees that remain green year-round [7]. The climate 
of the region is both hot and humid. Its southern part features wetland areas that do not favor settlement. The region's natural environment and local climate yield very specific living conditions.

The purpose of the study was to examine the living conditions of the population residing in Maya lands in southeastern Mexico as a manifestation of traditional lifestyle patterns and material culture. In the study, it was assumed that two key characteristics of traditional home construction are the material used to construct walls and roofs and the material used to construct floors. Statistical data were used to perform a spatial analysis of differences in building materials used to construct residential structures in the study area. The study area consists of three Mexican states located in the Yucatan Peninsula. Areas inhabited by the native population were identified in the course of the study. Most native inhabitants in the study area happen to be Maya residents who preserve key local traditions and lifestyles via their manner of home construction and living conditions.

\section{MAYAS IN THE YUCATÁN PENINSULA VERSUS OTHER ETHNIC GROUPS IN MEXICO}

A total of 19 ethnic groups in Mexico use some type of Maya language (Tab. 1) (XIII Censo General de Población y Vivienda). Almost 1/3 of the indigenous population in Mexico speaks a Maya language. The largest Maya community is that of the MayaYucateco Indians at almost 800,000 inhabitants. The second largest Maya community at 470,000 inhabitants $(6.8 \%$ of indigenous population) speaks the Tseltal language, while the third largest community at almost 430,000 inhabitants (6.2\% of indigenous peoples) speaks the Tsotsil language. The remaining ethnic groups speaking Maya languages in Mexico are much smaller. Most of the studied Maya groups live in the state of Chiapas. Of the 32 Mexican states, the largest percentage of Indians is found in Oaxaca, Yucatan, and Chiapas. More than $25 \%$ of the general population aged 3 or older speaks an Indian language. The most diverse region of Mexico in terms of the number of ethnic groups is the capital region of Distrito Federal and the surrounding state of Estado Mexico. This region is inhabited by 58 of the 70 ethnic groups officially identified by the government of Mexico [11], [13].

Table 1. Population speaking indigenous languages in Mexico and in the study area (2010)

\begin{tabular}{|c|c|c|c|c|}
\hline & \multicolumn{2}{|c|}{$\begin{array}{l}\text { The number of people aged } \\
3 \text { years and more speaking } \\
\text { indigenous languages }(2010)\end{array}$} & \multicolumn{2}{|c|}{$\begin{array}{l}\text { The percentage of people } \\
\text { aged } 3 \text { years and more using } \\
\text { one of the languages from } \\
\text { Mayan languages group in } \\
\text { the indigenous population }\end{array}$} \\
\hline & Mexico & $\begin{array}{l}\text { Campeche, } \\
\text { Quintana Roo } \\
\text { \& Yucatán }\end{array}$ & Mexico & $\begin{array}{l}\text { Campeche, } \\
\text { Quintana Roo } \\
\text { \& Yucatán }\end{array}$ \\
\hline Indigenous languages (in total speakers) & 6913362 & 835642 & 100 & 100 \\
\hline $\begin{array}{l}\text { Mayan languages group in total (number } \\
\text { of speakers) }\end{array}$ & 2207657 & 817275 & 31,93 & 97,80 \\
\hline \multicolumn{5}{|l|}{ Mayan languages (number of speakers): } \\
\hline Maya-Yucateco & 795499 & 787449 & 11,51 & 94,23 \\
\hline Tseltal & 474298 & 3461 & 6,86 & 0,41 \\
\hline Tsotsil & 429168 & 4367 & 6,21 & 0,52 \\
\hline Ch'ol & 222051 & 14530 & 3,21 & 1,74 \\
\hline Huasteco & 166952 & 50 & 2,41 & 0,01 \\
\hline
\end{tabular}




\begin{tabular}{lrrrr}
\hline Tojolabal & 54201 & 257 & 0,78 & 0,03 \\
\hline Chontal de Tabasco & 37224 & 376 & 0,54 & 0,04 \\
\hline Mam & 10467 & 2048 & 0,15 & 0,25 \\
\hline Q'anjob'al & 9625 & 3077 & 0,14 & 0,37 \\
\hline Chuj & 2632 & 312 & 0,04 & 0,04 \\
\hline Awakateko & 1997 & 17 & 0,03 & 0,00 \\
\hline Q'eqchi' & 1279 & 990 & 0,02 & 0,12 \\
\hline Lacandón & 926 & 1 & 0,01 & 0,00 \\
\hline Jakalteko & 602 & 68 & 0,01 & 0,01 \\
\hline K'iche' & 391 & 165 & 0,01 & 0,02 \\
\hline Qato'k/Motocintleco & 106 & 0 & 0,00 & 0,00 \\
\hline Kaqchikel & 103 & 36 & 0,00 & 0,00 \\
\hline Ixil & 83 & 71 & 0,00 & 0,01 \\
\hline Teko & 53 & 0 & 0,00 & 0,00 \\
\hline
\end{tabular}

Source: Own compilation based on XIII Censo General de Población y Vivienda, 2010 [1].

Indians constitute $29.5 \%$ of the general population (three years of age and older) of the Mexican state of Yucatan, $11.9 \%$ in Campeche, and $16.1 \%$ in Quintana Roo. The population of these three states speaking one of the Maya languages constitutes a clear majority among people speaking native languages in these states. More than $96 \%$ of the native population (aged 3 and older) speaks a Maya language in the states of Campeche and Quintana Roo. In the state of Yucatan, it is $99 \%$. The largest ethnic minority in the Mexican federation, the Maya Yucateco Indians, inhabit mostly regions of the Yucatan Peninsula, with the largest groups found in the three studied states: Yucatán, Campeche, Quintana Roo.

\section{TRADITIONAL MAYA HOMESTEAD AS AN EXPRESSION OF CULTURAL IDENTITY}

Traditional home construction in Mexico bears witness to the contemporary use of knowledge and skills honed during the Pre-Columbian era. It is important to note that while some key characteristics have remained static, the means of construction and also the materials used have been adapted to both constantly changing social and economic conditions and new planning requirements [8]. The architectural heritage of the original Maya civilization, which is recognized worldwide in certain forms, may be found in the ancient urban centers of the Maya region in the form of monumental stone structures mostly sacred sites and political monuments. Less frequently recognized are structures that used to serve a majority of citizens in the Maya city states. These structures include the homes of Maya peasants. These were constructed of nondurable materials and were the pillars of the Maya homestead known as a solar. There exists proof that houses with garden and orchards - resembling those of today - were in existence already prior to the arrival of Columbus in the late $15^{\text {th }}$ century. These houses experienced change over time but their overall form remains the same today. Historical houses of the original Maya peoples remain an important element of the cultural heritage still in use by the modern Maya population in Mexico [8].

A Maya homestead is an enclosed area featuring a complex system of traditional agricultural production. A typical solar includes crop production, animal husbandry, as well as craftwork whose primary purpose is to serve the needs of homestead owners. A solar will normally include several residential-type and farm-type buildings along with a 
number of small agricultural fields, spaces used to manufacture tools for daily use and spaces for building materials. In addition to agricultural products designed to meet the ongoing needs of its owners, a solar produces feed for animals kept within its bounds. A surplus in production - both in farm products and crafts - is sold at markets in the area in order to yield extra income for the farm family [6]. Hence, the land associated with a traditional homestead in Mexico serves as an important cultural element, which is very characteristic of the native Maya population. This type of space remains a prerequisite for biological and social continuity in the Maya community [5]. The social function of a solar is one of its most important characteristics. The area of the homestead functions as a space to help build and maintain family ties and social ties in general. This is reflected in part in the transmission of knowledge to future generations on the functioning of this complex agricultural and social system. The homestead is also a space for the creation of new adaptive strategies that allow a given family to earn an income and acquire the goods it needs to function on a daily basis [6].

In the Pre-Columbian period, the Maya homestead was rather dispersed, and was not limited by clear boundaries. This changed during the colonial era when homesteads were assigned specific amounts of land. This made it possible to create a more ordered system of homesteads limited by new roads [2]. In modern times, a typical solar found in the Yucatan ranges between $250 \mathrm{~m}^{2}$ and $1,000 \mathrm{~m}^{2}$ in surface area. This space serves as an area for the daily activities of a modern Maya family. It includes several buildings such as a main residence, separate kitchen, and various agricultural buildings. Other key features of the homestead include open spaces where the everyday activities of a family occur along with the functioning of the entire farm unit - animal husbandry, agriculture including crops and trees, and the manufacture of crafts.

One of the traditional elements of the spatial structure of a solar is the residence. This is a structure that links residential requirements with capabilities provided by the local natural environment. The research literature provides a special term for traditional residential structures built by the Maya in the Yucatan Peninsula: la vivienda vernácula [8]. The specific nature of traditional home construction is the product of centuries of local tradition, and the key methods needed to utilize natural construction materials are carefully transmitted to future generations. This is a fine example of a community that is able to adapt to local environmental conditions and the social and cultural landscape of its region. Every change in the construction method or in the raw materials used results in a change in the appearance of homestead buildings and their key characteristics; this also affects their physical shape and the functioning of the homestead as a whole [3].

A traditional home constructed by the Maya inhabiting the Yucatan Peninsula is oval in shape and does not possess corners (Fot. 1). Its typical dimensions are roughly 9 meters in length and 4 to 6 meters in width. Entrances are found along the longer sides of each home, which helps improve air circulation inside the home. The latter is very important in a hot and humid climate. The family home is most often situated along the boundary of the homestead and may lie directly adjacent to the street. In other cases, the home is situated in the middle of the homestead. Construction materials used to build the Maya home are natural and hail from local sources. It is estimated that somewhere between 35 and 45 plant types may be used as building materials in the construction of a traditional home. Roofs are covered with palm leaves. The main frame of the home is wooden. The walls are constructed in the shape of a palisade using thin vertical beams, which are then usually covered with clay mixed with dry grass and water [8]. A traditional Maya home has an earthen floor. The construction materials used to build the home are made by the 
residents of the future home themselves. Other members of the local community help in some instances in the production process as well.

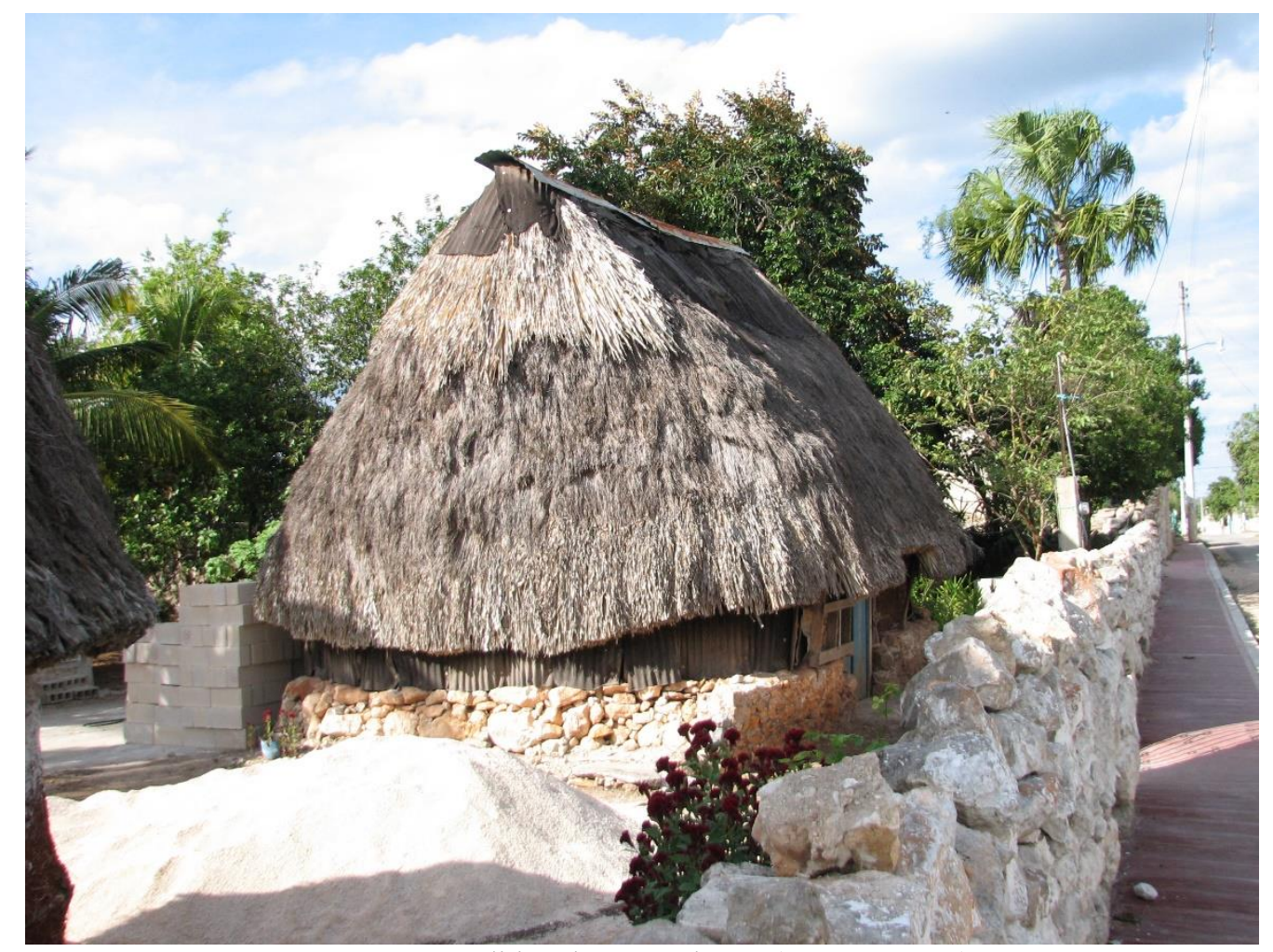

Figure 1. Traditional Maya's home (Cuzama town).

Sorce: author's work

The use of natural building materials makes it easier to link them with the local ecological cycle. In addition, the use of natural materials and the nature of the structure itself help traditional homes maintain a favorable thermal equilibrium. This protects the residents from excessive heat during the day and provides heat at night. The special wall cover helps assure air circulation inside the home [8]. The Maya home represents both a residential space and a recreational space. It is also a space designed to host craftworks, religious practices, and everyday life activities. The residential part of the home is quite modest in most cases and includes a closet, table, and space for religious devotion - this includes a small altar with images of Christian saints and also figures of Mayan gods in some instances. Hammocks are hung inside the home at night and are used for sleeping. The residential building is usually the largest structure inside a solar, which also includes other smaller structures. This includes a kitchen, which is most often located in a separate building. In rare cases, a kitchen will be found inside the residential structure. Materials used to construct a kitchen are also natural and include wood (sometimes this is a palisade structure) and palm leaves that serve to cover the roof. Walls are frequently not filled in with any material and possess a relatively loose structure, which enables the free exchange of air with the outside of the structure. The inside of the kitchen includes a traditional fireplace, which is used to prepare meals, along with necessary equipment.

Other buildings inside a Mayan solar perform a non-residential function in most cases and may include a grain and hay storage silo, pantry, toilet, area for washing one's clothes, chicken house, and barn. Many homesteads also feature a special area known as a cochinita pibil or an area used to prepare a traditional meal with the same name - this 
meal is characteristic of the Yucatan Peninsula. A critical element of the homestead is a well designed to yield drinking water. Wells used to be a very important part of the area landscape where finding groundwater is very difficult. Aside from karst wells and lakes in so-called cenotes, it is rare to find sources of groundwater in the region. The region's access to drinking water has improved in recent decades and municipal water mains are now available in some locations.

\section{TRADITIONAL FORMS OF CONSTRUCTION - THE CUZAMA MUNICIPALTY CASE STUDY}

Cuzama is a town of more than 3,500 inhabitants, located in the state of Yucatan in a rural township with the same name (Fig. 1). Traditional buildings were identified in Cuzama via field excursions in 2018 and Street View software by Google Maps (Fig. 2). A total of 218 buildings were identified in Cuzama with a structure that could be completely or in part considered traditional. Buildings labeled "traditional" were distributed in a rather regular pattern across the studied town, with the exception of its central part, which has a number of public institutions and service sector buildings.

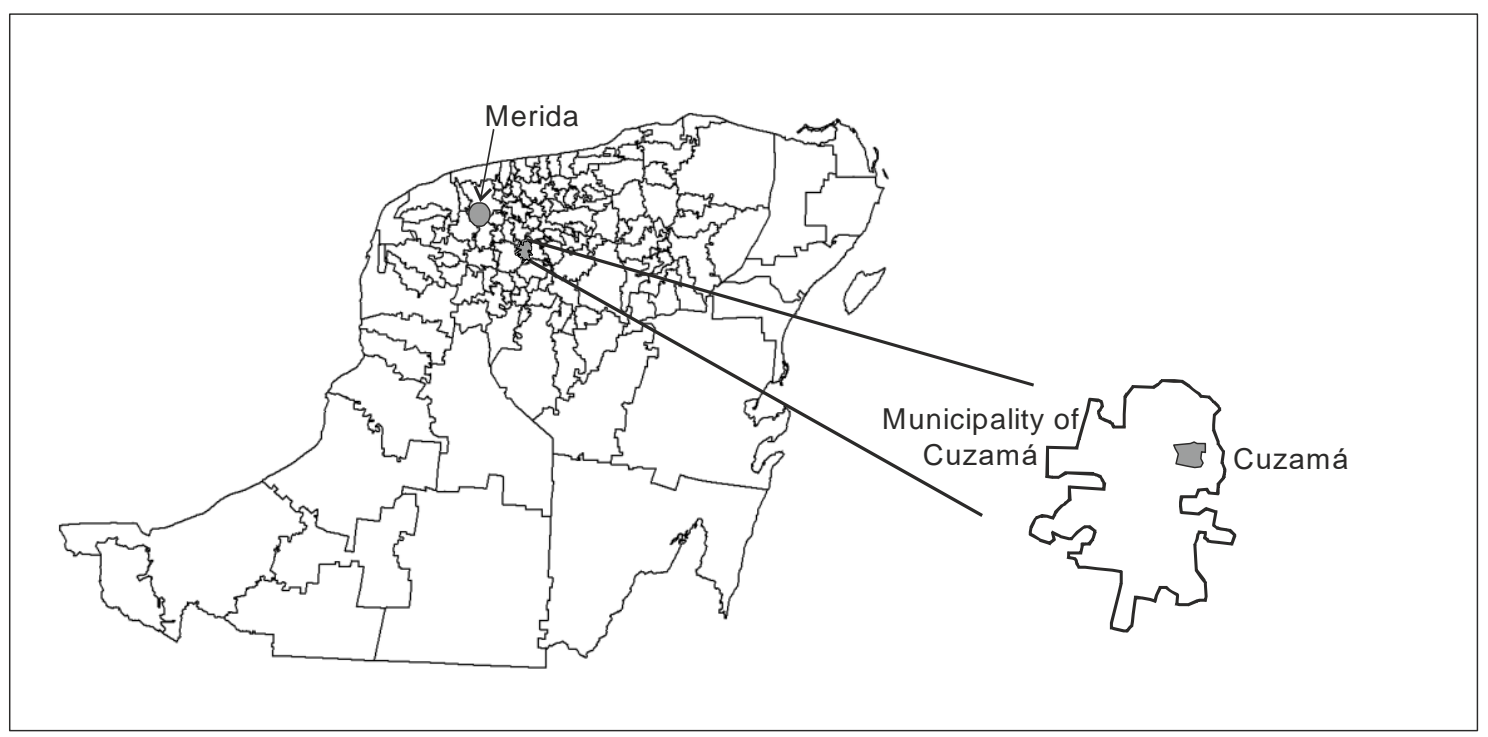

Figure 1. Localization of Cuzama town.

Source: own compilation.

The town of Cuzama has experienced a sort of boom in recent years thanks to a fairly new sector of the local economy - tourism. The town's residents have discovered that local cenotes represent a tourist attraction and can help generate income for locals. The main source of income for local residents serving tourists is transportation. It is this newfound popularity of the town that has yielded additional income for its residents - and whose ability to build new homes has greatly improved in recent years. Is often the case now that local residents abandon their traditional homes in favor of new buildings made of brick and mortar. Of the over 200 traditional buildings examined in this study, many are now used in conjunction with newer buildings. Some traditional buildings are put to new use. Sometimes a residential structure is turned into a kitchen or a farm-type building. In other cases, traditional Maya homes are simply abandoned and wither away in the elements. 


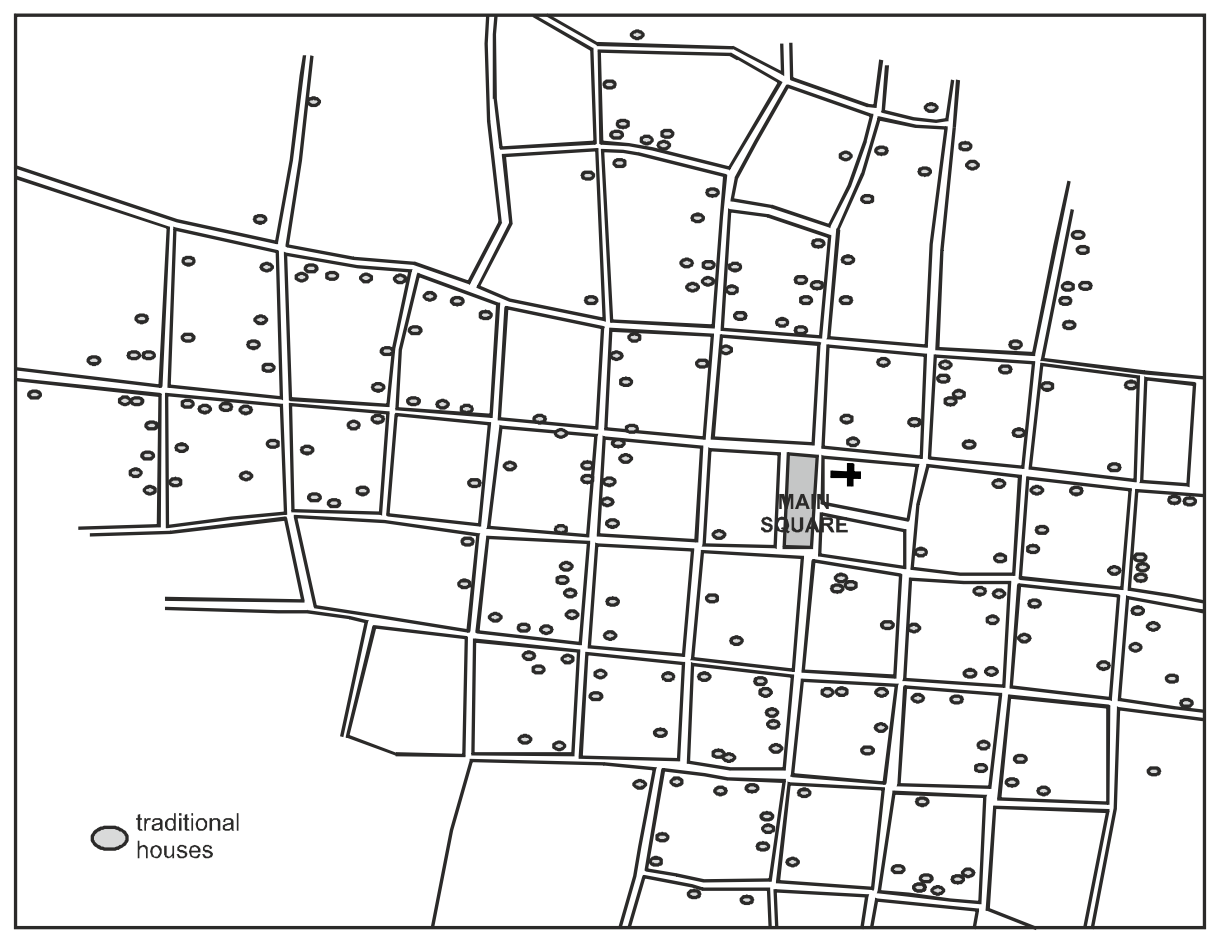

Figure 2. Traditional houses in Cuzama town.

Source: own compilation based on field work and Google Maps Street View

\section{MATERIALS USED TO BUILD HOMES IN THE MEXICAN PART OF THE YUCÁTAN PENINSULA}

Data for the year 2015 were acquired from Mexico's Statistics Institute (INEGI) in order to identify areas characterized by traditional home construction in the Yucatan Peninsula. The Institute's Encuesta Intercensal [4] in 2015 was a survey study designed to assess the housing conditions of local residents. The survey also inquired about home construction materials. The survey data were used to perform a spatial analysis of home construction materials for three states in the Yucatan Peninsula: Yucatan, Quintana Roo, Campeche. The survey focused on the spatial distribution of homes built using materials designated nondurable. The studied materials included materials used to construct walls, roofs, and floors.

The following roofing materials were deemed nondurable in the survey: carton, different types of waste, palm leaves, dried plant stalks, and panels made of asbestos or cement. The highest share of buildings covered using just one of the above types of roof coverage materials was noted in the southern part of the Yucatan Peninsula-more than $24 \%$ of the studied homes (Fig. 3). This region consists largely of rural areas and a few small towns. The smallest share of homes covered using materials deemed nondurable was noted in large cities such as Merida and Cancun as well as their immediate vicinity (less than 6\% of homes). Of the three examined states, the highest mean percentage of nondurable material homes was noted in Campeche (43\%), which was also higher than the national average $(21.7 \%)$. The two other states examined in this study ranked lower than the national average for Mexico: Quintana Roo (11.1\%), Yucatán (9.3\%). 


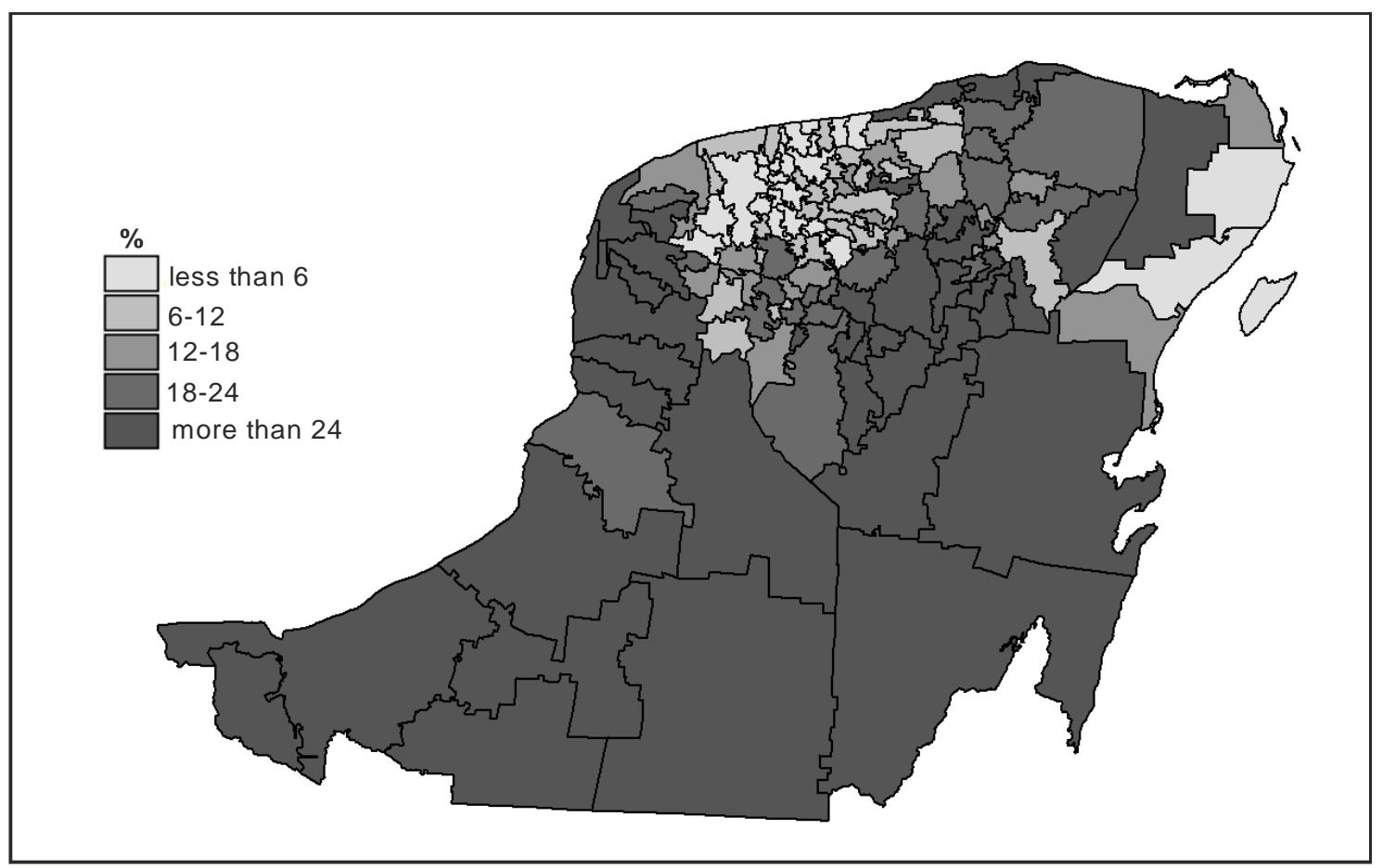

Figure 3. The share of homes covered using materials deemed nondurable.

Source: own compilation based on Encuesta Intercensal, 2015 [4].

In addition, homes with walls constructed using nondurable materials were also examined in the study. The survey by Mexico's Statistics Institute considered a number of wall construction materials to be nondurable: carton, bamboo, cane, palm, aluminum panels, asbestos panels, wood, adobe bricks formed of clay, mud, and silt mixed with a dose of dried grass blades or other plant stalks.

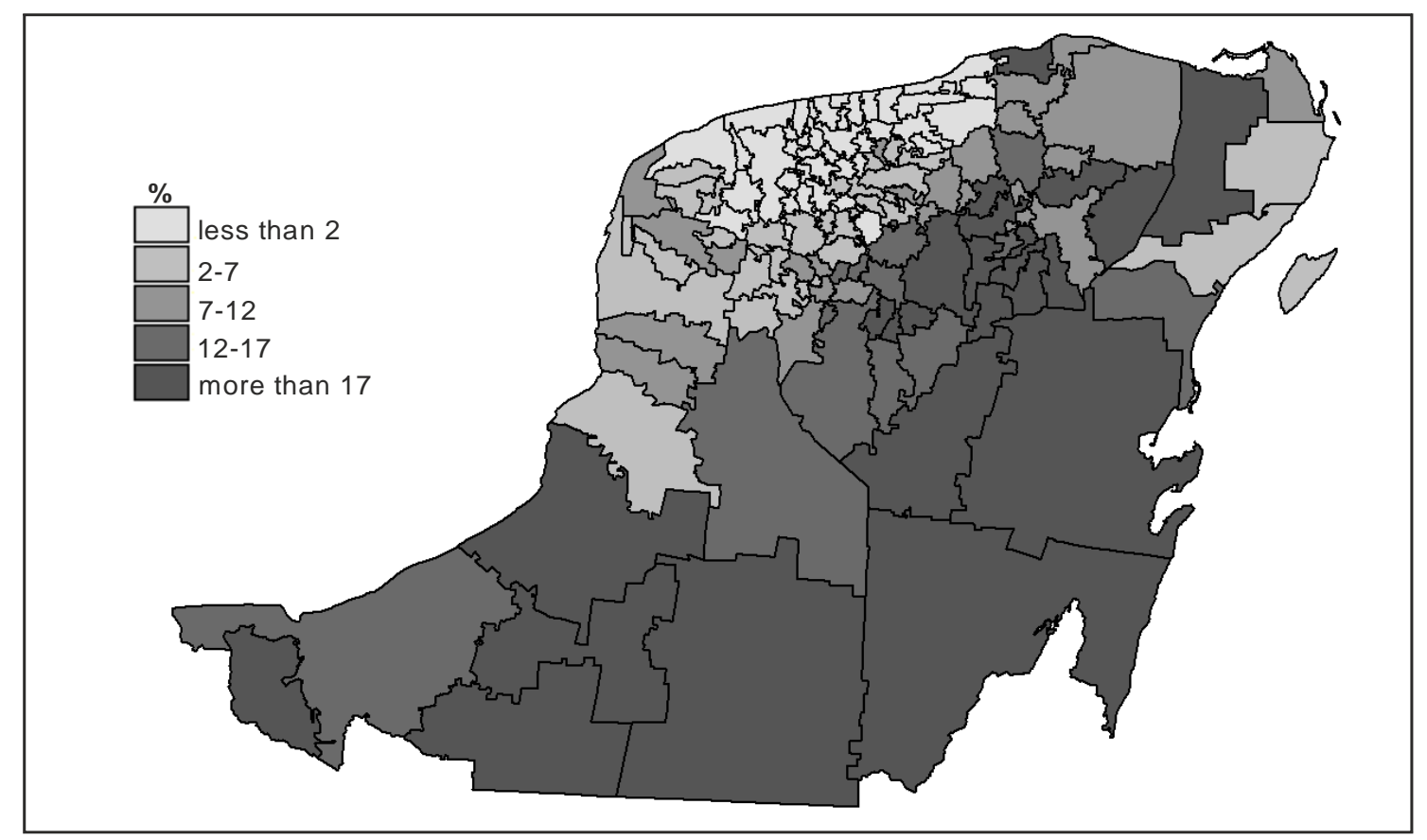

Figure 4. The share of homes with walls constructed using nondurable materials

Source: own compilation based on Encuesta Intercensal, 2015 [4]. 
The national average for nondurables is $10.7 \%$. As in the case of homes built with nondurable roofs, the percentage of homes in the Yucatan Peninsula built with walls made of nondurable materials was also above the national average in the state of Campeche $(15.7 \%)$. The two other studied states placed below the national average: Quintana Roo $(7.3 \%)$, Yucatán $(4.1 \%)$. The highest share of homes of this type, based on data at the township (municipio) level, was noted for both southern and eastern parts of the study area. The lowest share at less than $2 \%$ was noted in the northern part of the study area, especially in the metropolitan area of Merida and in the central districts of the city of Merida itself (Fig. 4).

The last home construction component examined in this study was the material used to build floors. Earthen floors were also considered as a traditional flooring type - and this is also a nondurable construction material. The national average for Mexico in the area of earthen floors is $3.5 \%$. In this case, all three examined states fell below the national average: Campeche $-3.1 \%$, Quintana Roo $-2.1 \%$, Yucatán $-1.6 \%$. When the data are examined on a township basis, the clearly emerging spatial pattern is that of an eastern part, southern part, and all other parts (Fig. 5). The eastern part does not include the city of Cancun as well as its metropolitan area. The first group of townships consists of townships with the share of homes equipped with nondurable floors at less than $4 \%$ (maximum of 14\%). The lowest percentages were calculated for the city of Merida and its metropolitan area.

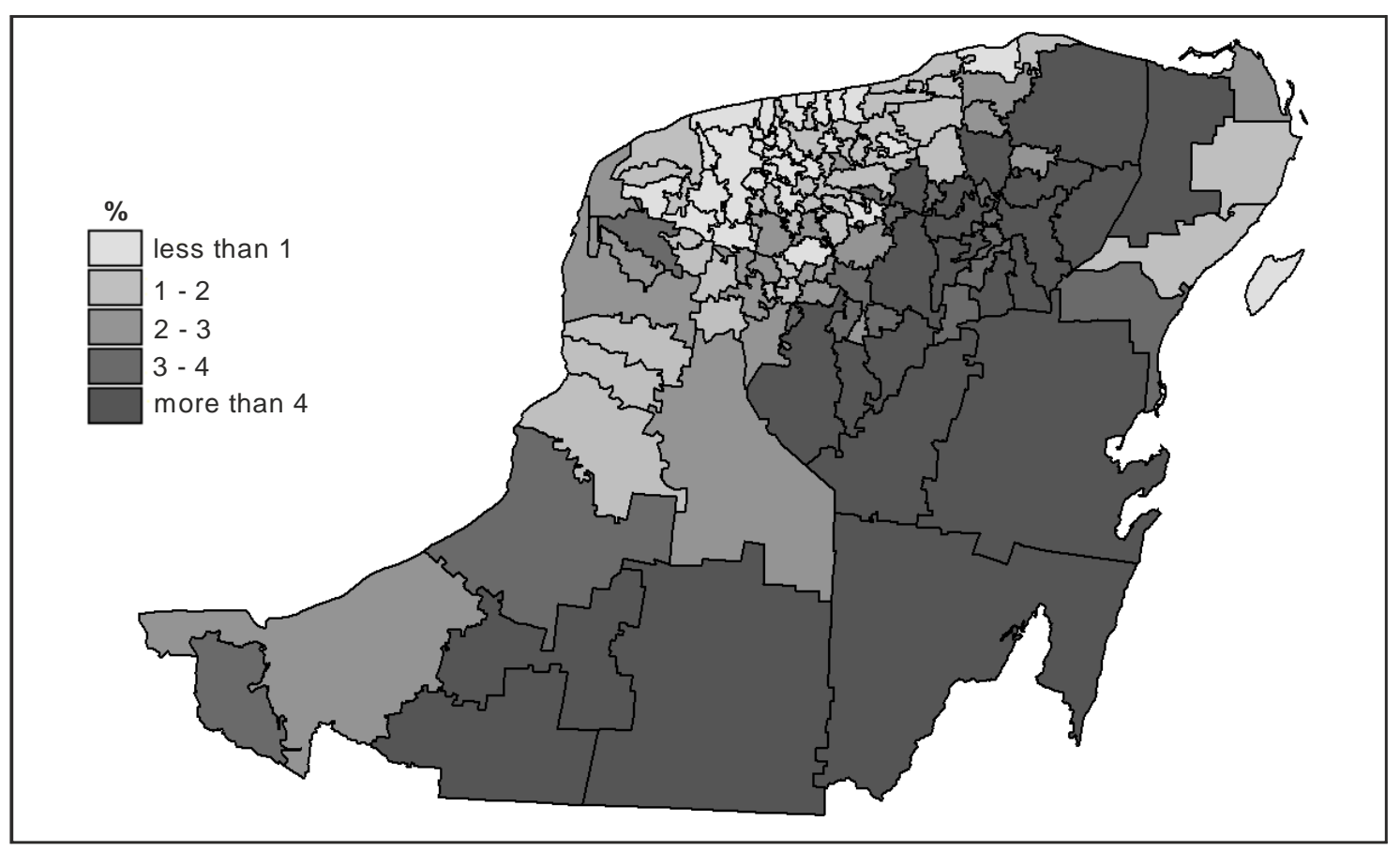

Figure 5. The share of homes with earthen floors

Source: own compilation based on Encuesta Intercensal, 2015 [4].

The statistical data available were used to construct a typology of townships for the Yucatan in terms of the percentage share of nondurable materials employed to build homes. Four residential building types were identified in the study area, where the value of each of the three aforementioned indicators was compared to the mean for the whole study area: 
- Type I - all three indicators above the mean

- Type II - two indicators above the mean, one indicator below the mean

- Type III - one indicator above the mean, two indicators below the mean

- Type IV - all three indicators below the mean

Figure 6 shows the spatial distribution of each identified type. The pattern is that of regionalization of townships with a majority of homes built of nondurable materials. Townships with all three indicators above the area average (Type 1, 33 townships) were located primarily in the southern and central parts of the Yucatan Peninsula. Townships with all three indicators below the area average (Type IV) were located primarily in the close vicinity of key regional cities such as Merida and Cancun. Type IV accounted for the largest number of townships in the study area -63 townships. The smallest number of townships was distributed between the two intermediate township types: Type II (11 townships, Type III (19 townships). The location of intermediate townships tends to be transitional in nature between Type I and Type IV. This indicates a gradual move away from traditional home construction in rural areas in the central and southern parts of the study area towards home construction based on more durable materials such as cement, concrete, and stone in more urbanized areas in the Yucatan Peninsula.

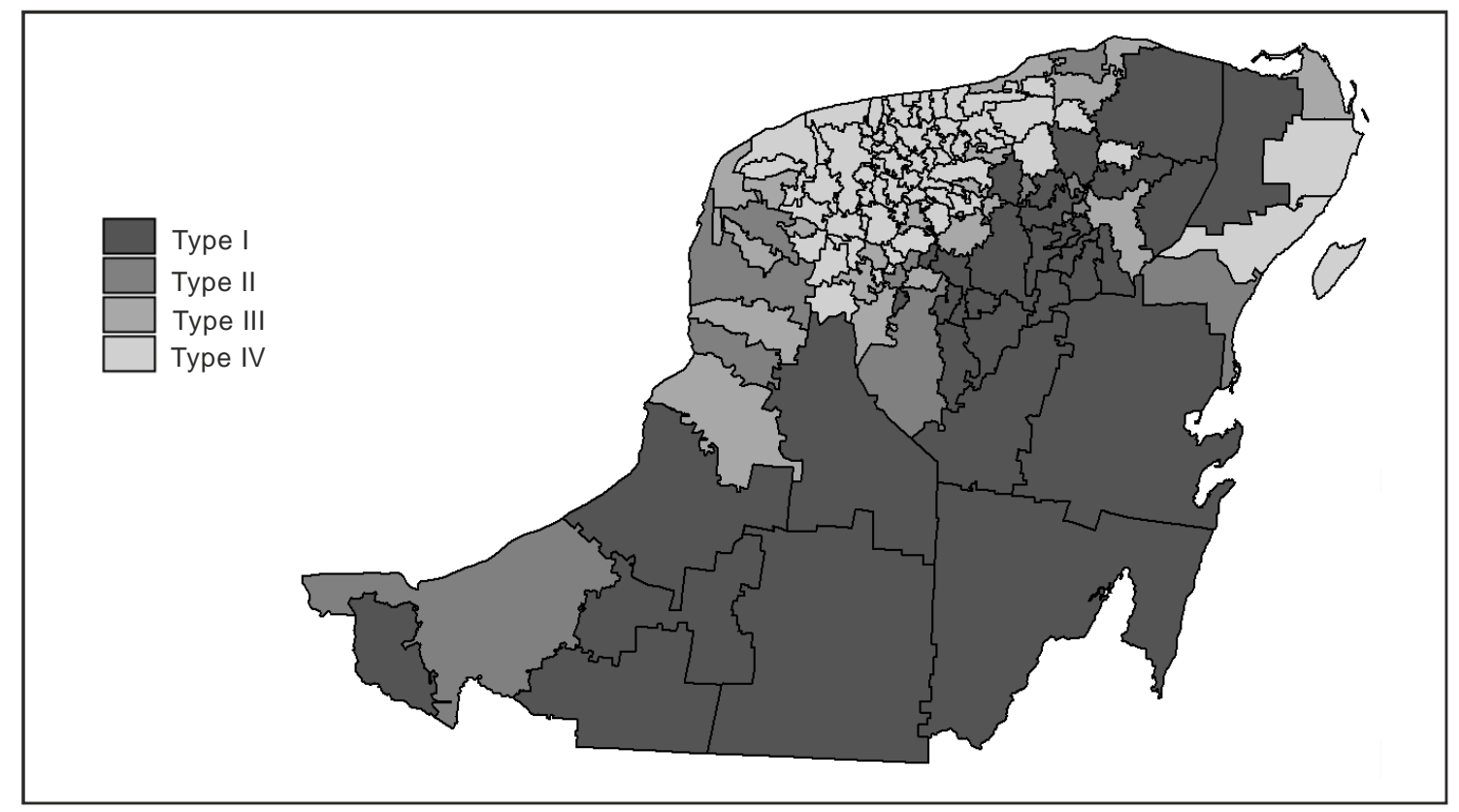

Figure 6. Typology of townships for the Yucatan in terms of the percentage share of nondurable materials employed to build homes

Source: own compilation based on Encuesta Intercensal, 2015 [4].

\section{SUMMARY}

In the modern world, traditional home construction is just one of the many main options available to individuals seeking to build or buy a home. In the Yucatan, there is still a fairly large group of residents who take advantage of this option. The prevalence of this type of home construction method most likely results from the socioeconomic status of the region's residents rather than from any benefits derived from this specific home building method [8]. The abandonment of traditional home construction methods in the 
study area results from both modernization and general economic development as well as changes in lifestyles considered to be backward by modern Mexican society in cases where nondurable natural materials are replaced with modern equivalents such as foil, asbestos, and sheet metal [3]. This is readily observable in the spatial distribution of buildings constructed of nondurable materials - higher rates of usage of nondurables are noted in rural areas and small towns. The usage of nondurables in major cities such as Merida and Cancun is negligible. It is likely that large cities will continue to expand in the future and suburbanization will lead to a decline in traditional Maya housing. This is particularly likely in the case of rapidly expanding Cancun, where traditional housing is being replaced with tourism-related housing and infrastructure [12].

What is often forgotten is the array of benefits derived from traditional methods of home construction. This trend applies both to Mexican society and its government. In particular, the key benefit of traditional home construction is the use of natural materials and traditional technologies. Both may serve as a basis for development based on ideas associated with sustainable growth of societies and regions. In addition, the traditional form of economic life known as homesteading (living within a solar) may constitute an important way of finding opportunities to survive for Mayan families living in poverty. The solar provides a place to produce food and other basic products needed to survive poverty. An additional benefit derived from traditional architecture is the ability to build and maintain ethnic and regional identity by combining tradition, customs, and defined physical spaces that foster family functioning and by extension community functioning. The use of traditional housing methods along with culturally characteristic customs and forms of dress also yield an immensely important element of tourist attractiveness for a given geographic region. In addition to drawing tourists with its beautiful areas of sandy beaches, historical sites, and natural attractions, the Yucatan Peninsula attracts tourists with its characteristic culture associated with the present-day Mayan community [9].

\section{ACKNOWLEDGMENTS}

"Study within the framework of the grant of National Science Centre, Poland no. 2017/01/X/HS4/00800"

\section{REFERENCES}

[1] XIII Censo General de Población y Vivienda, Instituto Nacional de Estadística y Geografía, México, D.F., 2010.

[2] Baños Ramírez O. Hamaca y cambio social en Yucatán, Revista Mexicana del Caribe, vol. VIII, pp 169-214, 2003.

[3] Cabrera Pacheco A. J. Estrategias de sustentabilidad en el solar Maya Yucateco en Mérida, México, GeoGraphos Alicante, Grupo Interdisciplinario de Estudios Críticos y de América Latina (GIECRYAL) de la Universidad de Alicante, vol. 5 (56), pp 1-32, 2014. DOI: 10.14198/GEOGRA2014.5.56

[4] Encuesta Intercensal, Instituto Nacional de Estadística y Geografía, México, D.F., 2015.

[5] Estrada Lugo E. \& Bello Baltazar E. \& Serralta Peraza L. Dimensiones de la etnobotánica: el solar maya como espacio social [in:] Cuevas S.J.A. \& Cedillo P.E. \& Muñoz O.A. \& Vera C.P. (Eds.), Lecturas en Etnobotánica. Publicaciones del Programa Nacional de Etnobotánica, Chapingo, Universidad Autónoma Chapingo, 1998.

[6] Jiménez-Osornio J. \& Ruenes Morales M. \& Montañez Escalante P. Agrodiversidad de los solares de la península de Yucatán. Revista Red. Gestión de Recursos Naturales, pp 30-40, 1999.

[7] Geografia regionalna Ameryki Łacińskiej, Warszawa, 1985.

[8] Sánchez Suárez A. La casa Maya contemporánea. Usos, costumbres y configuración espacial. Península, vol. 1(2), pp 81-105, 2006. 
[9] Winiarczyk-Raźniak A. \& Raźniak P. Poziom zadowolenia turystów zagranicznych a perspektywy wzrostu ruchu turystycznego w Meksyku, [in:] Procesy przemian przemysłu i usług w wybranych krajach, Prace Komisji Geografii Przemysłu Polskiego Towarzystwa Geograficznego, vol. 16, Warszawa - Kraków, pp 251-258, 2010.

[10] Winiarczyk-Raźniak A. Majowie w Meksyku, [in:] M. Soja \& A. Zborowski (eds.), Człowiek w przestrzeni zurbanizowanej, Kraków, pp 111-119, 2011.

[11] Winiarczyk-Raźniak A. Zróżnicowanie etniczne a warunki życia ludności w Ciudad de México (Distrito Federal), Prace Geograficzne, Instytut Geografii i Gospodarki Przestrzennej UJ, vol. 129, pp 43-61, 2012.

[12] Winiarczyk-Raźniak A. Obszary metropolitalne Meksyku, [in:] K. Kuć-Czajkowska \& M. Sidor (eds.), Miasta, aglomeracje, metropolie - w nurcie globalnych przemian, Katolicki Uniwersytet Lubelski, Lublin, pp 133-149, 2014.

[13] Winiarczyk-Raźniak A. \& Raźniak P. Ethnic minorities in Ciudad de México (Distrito Federal), Procedia-Social and Behavioral Sciences, vol. 120, pp 90-97, 2014. DOI: 10.1016/j.sbspro.2014.02.085 